Article

\title{
Fewer and Later: Women as Experts in TED Talks about COVID-19
}

\author{
Maider Eizmendi and Simón Peña-Fernández *(D)
}

Journalism Department, University of the Basque Country, 48940 Leioa, Spain; maider.eizmendi@ehu.eus

* Correspondence: simon.pena@ehu.eus

\begin{abstract}
The dissemination of science has undergone a major upsurge in recent years thanks to the Internet, which has served to overcome many of the technical and economic barriers. Among the many initiatives, one of the most successful tools has been the TED Talks website. At the same time, various studies indicate that women produce less science dissemination content and that they are also more likely to receive hostile comments. The objective of this research is to analyze from a gender perspective the content published on the TED Talk website on COVID-19 from 1 March 2020 to 31 March $2021(n=62)$ to determine its characteristics and the topics addressed, as well as the resulting engagement and the predominant feelings of the comments received. To do this, a content analysis of the publications has been carried out, as well as a qualitative analysis of the comments. The results indicate that the percentage of women experts on this platform is slightly lower than that of men $(42.19 \%)$, and they have published content in later phases of the pandemic. From a qualitative point of view there are also differences, since women mainly opt for a social, political and social approach to the issue. In addition, the engagement of their publications is lower than that of men, although a higher prevalence of negative feelings is perceived in the comments they receive.
\end{abstract}

Citation: Eizmendi, Maider, and Simón Peña-Fernández. 2021. Fewer and Later: Women as Experts in TED Talks about COVID-19. Journalism and Media 2: 808-818. https://doi.org/ 10.3390/journalmedia2040046

Academic Editor:

Andreu Casero-Ripollés

Received: 31 October 2021

Accepted: 30 November 2021

Published: 2 December 2021

Publisher's Note: MDPI stays neutral with regard to jurisdictional claims in published maps and institutional affiliations.

Copyright: (c) 2021 by the authors. Licensee MDPI, Basel, Switzerland. This article is an open access article distributed under the terms and conditions of the Creative Commons Attribution (CC BY) license (https:// creativecommons.org/licenses/by/ $4.0 /)$.
Keywords: TED Talk; gender; COVID-19; dissemination; science; engagement

\section{Introduction}

The dissemination of science has undergone a major upsurge in recent years (DiviuMiñarro and Cortiñas-Rovira 2020). Although the communication of research has always been a fundamental part of academic work (Côté and Darling 2018), the demand to convey results to society has grown at an increasing pace, with calls for the scientific community to commit to and engage with society, and to facilitate the relationship between the scientific world and the world of laypeople (Anzivino 2021).

To undertake such explanatory efforts, the scientific community has made ever greater use of online media (Sugimoto et al. 2013), since the Internet has served to overcome many of the technical and economic barriers (Peters et al. 2014), and has facilitated experimentation with new formats, such as audiovisual techniques.

Among the many initiatives that have emerged within the digital ecosystem to foster dissemination, one of the tools that has proved most successful has been the TED conference and event website. Having arisen in 1984 as a debate forum for technological, entertainment, and design matters, in 2006 it broke into the global market and began to broadcast videos of talks and conferences via its website and YouTube. According to the TED site itself, within six years it had already clocked up a billion views. This dissemination channel represents a professional presentation genre that is effective at communicating innovative, technical information to a wide audience with the potential for supporting and engaging with an issue or idea (Kedrowicz and Taylor 2016), and thus provides an authentic environment for examining aspects of online participation (Veletsianos et al. 2018). The published content now covers a wide range of topics, and is available in over 100 languages.

Within the context of the global COVID-19 pandemic, sites such as TED have played a crucial role in response to the need to link up science and society in addressing the 
uncertainty triggered by the health crisis, within the context of an upsurge in disinformation and fake news (Pérez-Dasilva et al. 2020; Sierra-Rodríguez 2020; Ceron et al. 2021). Although, as in previous health crises, television has been the most widely consumed medium (Casero-Ripollés 2020), digital and social media have also played an essential role.

However, we have again seen an imbalance in the presence of women and men in this task of dissemination over the course of the pandemic. Additionally, despite the numerous initiatives undertaken to achieve equality in the field of science, the gender gap remains present in this sphere. In a situation of high demand for and the impact of scientific information with regard to society, the scientific productivity of women and their visibility in the sphere of dissemination has been limited (Andersen et al. 2020; Wright et al. 2021; Chinetti 2021; King and Frederickson 2021).

The gap in the presence of men and women in scientific communication dates back a long way, with existing studies in this regard indicating that the quantity (Mueller et al. 2016; Larivière et al. 2013) and the impact (Duch et al. 2012) of research varies according to the gender of the authors. Studies which have researched the factors associated with this phenomenon have identified such reasons behind this inequality as difficulties in achieving a work-life balance (Myers et al. 2020; Krukowski et al. 2021; Deryugina et al. 2021; Palomar Verea 2009), asymmetries in academic work and in the levels of responsibility that men and women have when working in teams (Pereira 2021), and existing social stereotypes about people engaged in science (Carli et al. 2016). The boom in scientific information triggered by the COVID-19 pandemic has likewise been affected by this trend (Krukowski et al. 2021; Pereira 2021), since academic journals have themselves indicated that during this period, they have received fewer texts produced by women (Andersen et al. 2020; Wright et al. 2021).

If we focus on dissemination over the Internet, although there has been an increase in the number of female TED Talk speakers (Schwemmer and Jungkunz 2019), we likewise find that women are less represented as producers of explanatory content via channels such as YouTube (Welbourne and Grant 2016). This not only entails reduced participation and visibility in scientific debate (Cambronero-Saiz et al. 2021), but also a reduced opportunity to underpin their personal brand, which is very closely tied to the expectations, images, and perceptions created about an individual (Kalia et al. 2017).

The visibility of female scientists through these channels can affect their social image. Various studies have observed the scarce presence of female scientists in both traditional and digital media (Aladro et al. 2014; Mitchelstein et al. 2019), and have also indicated that the image that is projected is biased and stereotyped (Husu and Tainio 2016; Mitchell and McKinnon 2019).

Likewise, studies that have focused on the comments received by experts from a gender perspective have indicated that, in the case of YouTube, for example, female academics are more likely to receive hostile comments than their male counterparts, and receive greater hostility and comments that are sexual or to do with their appearance, as well as more negative criticism (Amarasekara and Grant 2019). Furthermore, in the case of TED Talks, users tend to be more "emotional" when the content author is a woman (Tsou et al. 2014).

Within this context, the purpose of this research is to analyse, from a gender perspective, the audiovisual content published on the TED Talks site about COVID-19: the characteristics of the publications, the topics most commonly addressed, and their engagement and the sentiments that predominate in the comments they receive.

The following research questions are raised for this purpose: RQ1-Has there been a difference in dissemination activity by men and women on this platform? RQ2-Is there a difference in the topics addressed by men and women? RQ3-Are there differences in audience interaction and dialogue depending on gender? 


\section{Methodology}

To analyse the impact of gender on scientific dissemination, all videos about COVID-19 published on the TED Talks site and corresponding to the keywords "covid", "coronavirus", or "pandemic" were selected.

The selected period ran from 1 March 2020 until 31 March 2021 (13 months). This timeframe allows one to study the development of dissemination content during the most acute phase of the pandemic.

The manual registration process resulted in the identification of 62 videos $(n=62)$, following exclusion from the sample of those making only circumstantial reference to the topic.

The transcripts of the video content were used to conduct a content analysis so as to analyse the texts in a systematic, objective and quantitative manner (Wimmer and Dominick 1996). This investigation technique has typically been used in research into scientific journalism, and also on the Internet (Andreu 2001).

The content was codified by means of the categories established for each of the variables. Under authorship (RQ1), the gender of the authors of the talks was identified. In total, there were 60 videos published with individual authorship, one involving two men, and another involving a man and a woman. The individuals involved were likewise subdivided in accordance with their profile: academic and non-academic.

To analyse the topics (RQ2), seven categories were established on the basis of a deductive exploration, serving to define and characterise the categories. Since various topics could arise over the course of the talks, they were categorised in accordance with the main topic set out in the presentation of the theme. The topic categories were thus defined as follows: health, society, economy, politics, technology, climate change, and art. The topic analysis considered the platform content offering a transcript $(n=31)$, as well as the comments registered for the same publications by means of the YouTube Data Tools software.

Lastly, to analyse audience interaction (RQ3), the publications comprising the sample were codified on the basis of the following variables: number of views on TED Talks, number of views on YouTube, number of likes, number of dislikes, and number of comments.

The analysis of the topics and audience engagement excluded the only video produced jointly by a man and a woman, since it could not be analysed in accordance with male or female authorship.

Both the registration and the descriptive and statistical analyses of the data were conducted by means of Microsoft Excel. The qualitative analysis applied to the comments generated by users in order to discern the predominant sentiments was conducted using the program QSR NVivo (version 12).

\section{Results}

\subsection{Authorship of Dissemination Content}

The aim of the descriptive analysis of the content involved analysing the main characteristics of the videos comprising the research universe $(n=62)$ from a gender perspective. In total, without taking into account the moderators of the TED platform itself, a total of 64 people were involved, where $57.81 \%$ of them were men, and $42.19 \%$ women.

As for the participants' profiles, of the 64 experts, $37.5 \%$ were academics, while $62.5 \%$ did not come from an academic or scientific sphere. This latter group included professionals from the field of business, journalists, as well as activists and political representatives. The presence of women was greater in the academic sphere (48.83\%) than among non-academics $(40 \%)$ (Figure 1). 


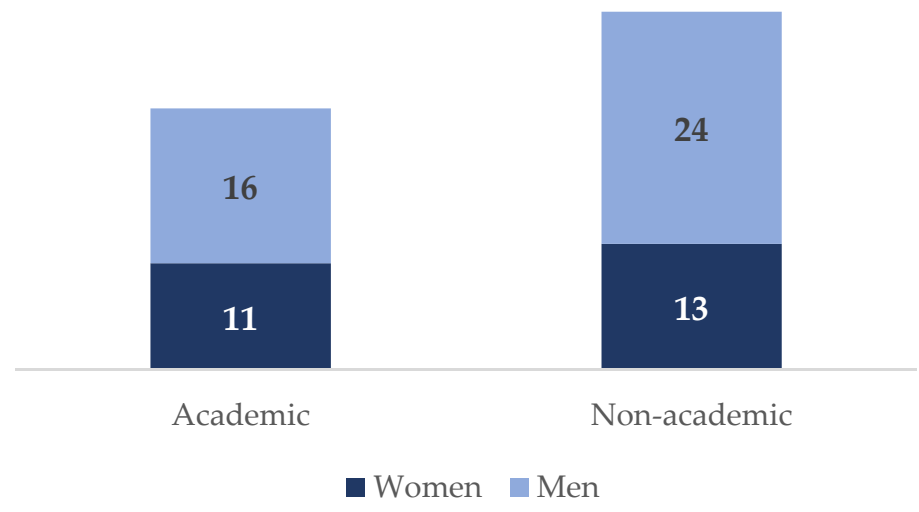

Figure 1. Distribution of authorship, by gender and profile.

Meanwhile, an analysis of the distribution of publications over time offers relevant data. We first find a significant spike in interest during the first five months of the pandemic, from March to July 2020. During this period, 55 videos were published on the TED Talks platform; in other words, almost 9 out of 10 videos from the total for the period analysed $(88.71 \%)$. From this point onwards, activity was significantly lower (Figure 2).

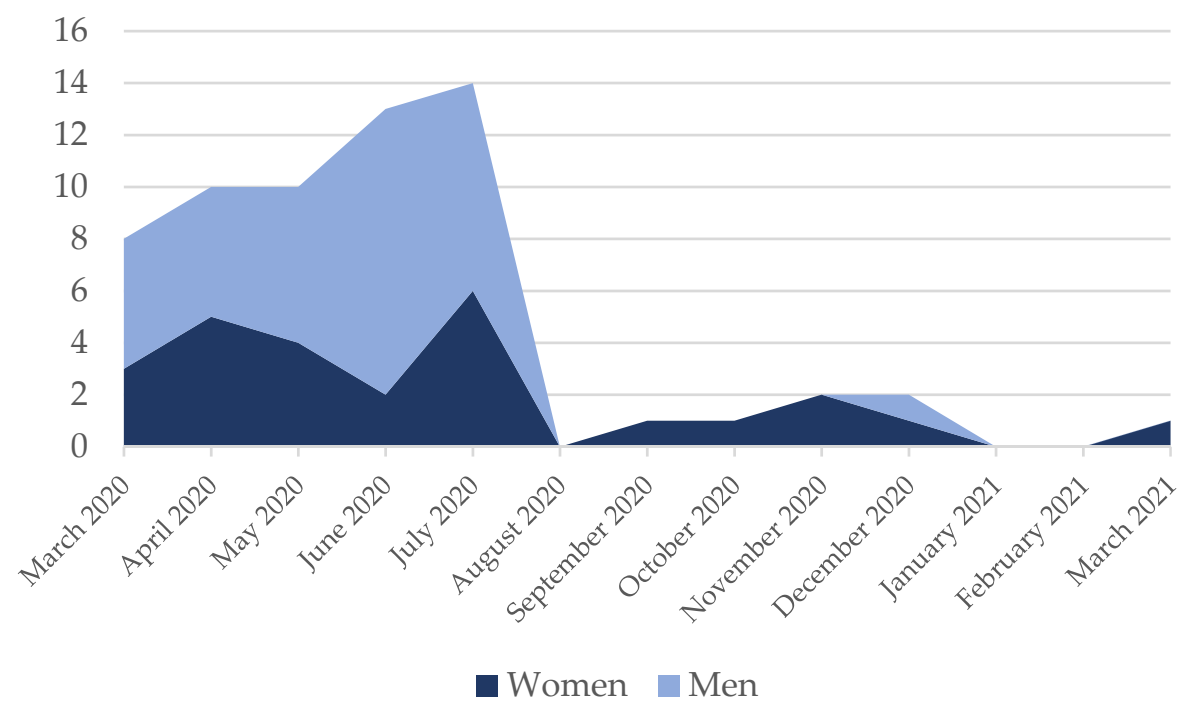

Figure 2. Distribution of publications over time, by gender.

\subsection{Topics}

As for the types of content, most of the videos analysed corresponded to interviews $(46.77 \%)$ or individual presentations $(37.10 \%)$, although the sample also included talks by more than one person, or excerpts from a group activity $(6.45 \%)$, as well as animated videos $(9.68 \%)$. It should be pointed out that the measures adopted to halt the spread of the virus made it impossible to stage events, which would explain the significant prevalence of interviews, most of them conducted remotely. In turn, the six animated videos included in the sample, which adopted an educational approach as to preventive measures, the characteristics of the virus, symptoms, the creation of vaccines, the use of mechanical ventilators and the possible responses to a pandemic, showed significant capacity for engagement.

As may be seen, women were proportionally more involved in talks, while men were, to a greater extent, the focus of interviews (Figure 3). 


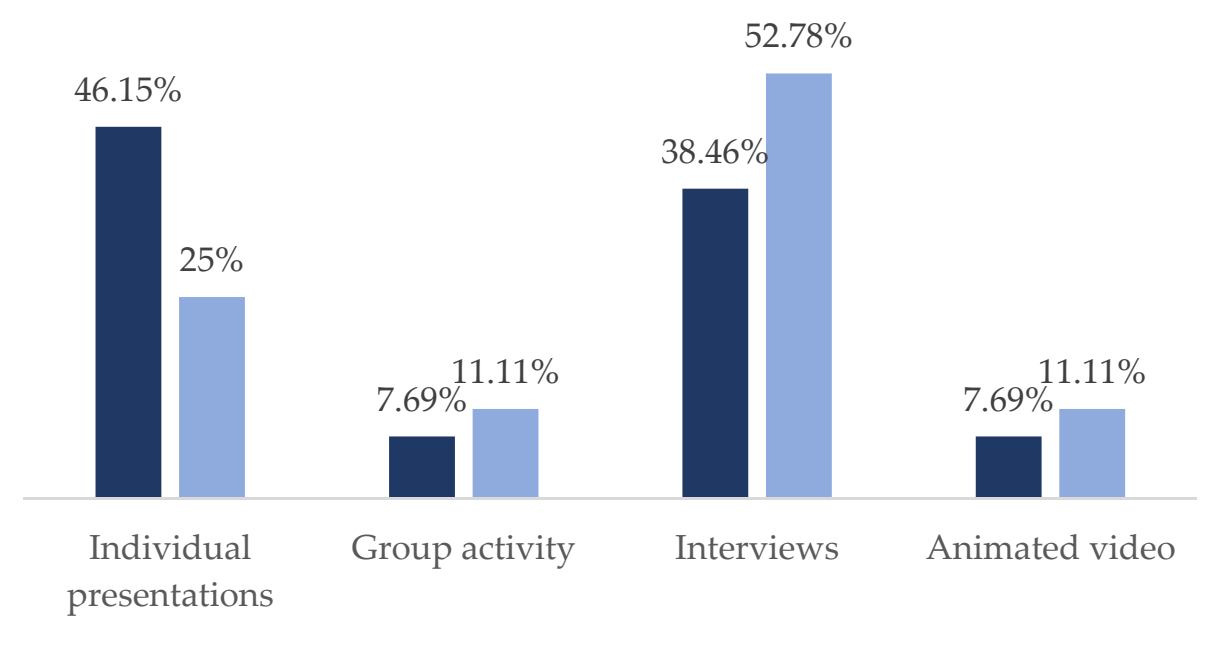

- Women Men

Figure 3. Distribution of contributions, by type and gender.

As for the topics covered, the results show that although the origins of the COVID-19 crisis essentially lie in the field of healthcare, the situation derived from the pandemic had consequences in numerous spheres, as reflected in the multi-topic approach found in the sample analysed.

Of the topics addressed during the analysed period, health and social aspects were the most common, accounting for $32.26 \%$ and $22.58 \%$, respectively. They were followed by those adopting perspectives on economics $(16.13 \%)$, technology $(9.68 \%)$ and politics $(8.06 \%)$. Albeit to a lesser extent, there were also videos which, although their central focus was on COVID-19, considered the issue from the perspective of climate change $(8.06 \%)$ and artistic expression (3.23\%).

As may be seen in the results (Figure 4), women had a greater presence in topics such as art, politics, and society, but less so in climate change, technology, and health.

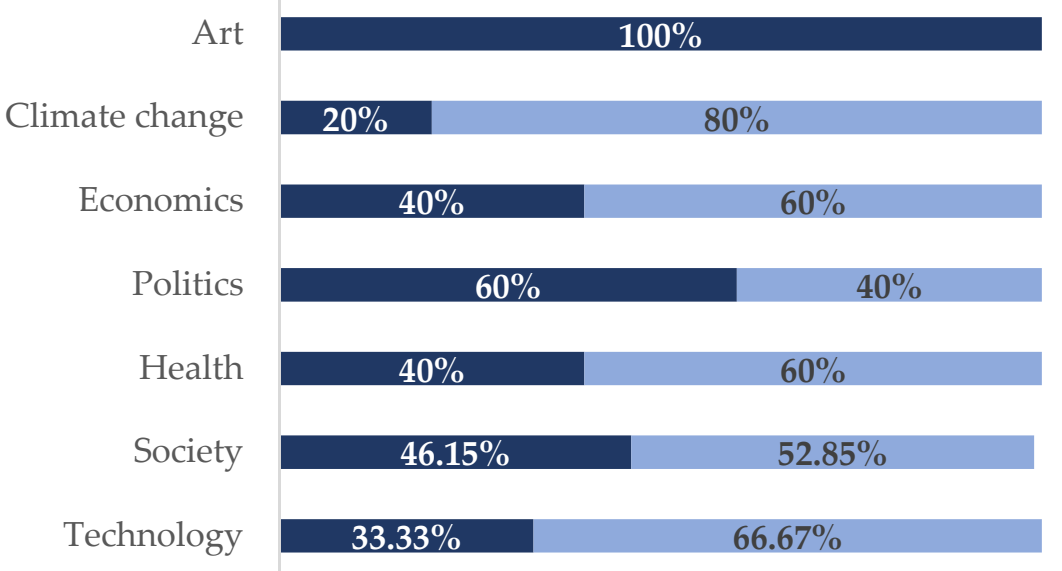

Women Men

Figure 4. Distribution of topics connected with COVID-19, by gender. Source: Produced by the author.

\subsection{Interaction and Dialogue}

To measure interaction and dialogue, the number of views, number of likes and dislikes, and number of comments generated were analysed (Table 1). As described in the methodology, the number of views of each unit of analysis were counted and registered, 
both on the TED Talks site and on YouTube, if the content was published on the stated platform.

Table 1. Average number of interactions received, by gender.

\begin{tabular}{cccc}
\hline & Likes & Dislike & Comments \\
\hline Man & $11,992.22$ & 1197.06 & 1998.53 \\
Woman & 9097.25 & 686.71 & 1033.66 \\
\hline
\end{tabular}

Source: Produced by the author.

The number of views on the TED Talks platform was noticeably higher. According to the data obtained, the videos comprising the sample were viewed 77,430,394 times, while there were 28,025,965 views on YouTube. In other words, the number of views on YouTube was 2.76 times lower than on TED Talks. It is important in this regard to note that in the case of TED Talks views, the standard deviation is 1,320,087.429, an aspect to be taken into account when considering the mean values. Despite the existing differences between the two websites, it may be noted that the interests of users are aligned across both platforms, since the number of views reveals a similar trend, at least for the content with the highest number of views.

It is likewise of interest here to analyse the existing correlation between the number of views and the author's gender. One may, for example, observe that content produced or fronted by women registered an average of 910,976.04 views on the TED Talk platform, compared with 1,488,094.14 for men. On YouTube, content offered by women has an average of 404,399.5 views, as opposed to $570,994.9$ for videos produced by men. There is, then, a significant difference in the visibility of the content created by each gender. On the TED Talks platform, videos produced by men receive $63.35 \%$ more visits than in the case of women, while the figure for YouTube amounts to $41.20 \%$.

However, in order to properly assess these data, it is necessary to take into account that, on the one hand, the metrics are constantly evolving and that, therefore, the fact that women are later when publishing probably affects the number of views; and, on the other hand, that as mentioned above, the topic has aroused more evident interest in the first months of the sample.

To analyse interaction, it is likewise of interest to analyse the concepts and sentiments conveyed, and to compare them with the content of the videos. A selection was, to this end, made of those publications which provided a transcript in English on the TED Talks site and were published on YouTube $(n=31), 11$ of which corresponded to women, and 19 to men.

This sample was used to perform an automatic codification of the content to ascertain the 10 predominant concepts in these documents, distinguished by the gender of the speaker. Overall, the content providing a transcript revealed predominantly healthcarebased topics (Table 2), although the identified nodes demonstrate that in the case of women's content, the social component is more significant, while in the case of men, we found a greater proportion of aspects connected with medical advances. These data corroborate those already obtained in the distribution of the set of videos by topic.

The analysis of the most frequently recurring words in the videos, and their comparison against those that are most common in the comments, meanwhile serves to analyse the degree of alignment between the publication and the interaction generated, on the basis of the speakers' gender.

In the case of content, healthcare issues were broadly addressed, as may be seen in the most commonly employed nouns. However, in the case of women (as indicated in the analysis of the main nodes), we note a more social and even more political component of the topic, and in the case of men, a more explicitly healthcare-based component. 
Table 2. Most recurrent concepts in the content and comments, by gender.

\begin{tabular}{cccc}
\hline & Men & & \multicolumn{2}{c}{ Women } \\
\hline Contents & Comments & Contents & Comments \\
\hline People & People & People & People \\
World & Virus & Health & China \\
Right & China & Public & Virus \\
Health & World & Covid & Chinese \\
Vaccine & Vaccine & Countries & Coronavirus \\
China & https & Contact & Government \\
Countries & Pandemic & World & Video \\
Virus & Video & Virus & Youtube \\
Government & YouTube & Right & World \\
Public & Gates & Crisis & Covid \\
\hline
\end{tabular}

Source: Produced by the author.

This difference may likewise be observed in the most common words in the comments, although in both cases there is, for example, evidence of interest in the platform itself, as well as the characteristics of the virus and its origins.

The same sample $(n=31)$ was used to analyse the predominant sentiments in the comments, by means of automatic codification using the categories established by the QSR NVivo program, which make it possible to know the emotional tone of the sentences in the context of the comment. If one observes the mean values (Table 3), the conclusion is that the general trend reveals a critical attitude by users, bearing in mind that in general, clearly negative sentiments $(27.79 \%)$ exceed clearly positive sentiments $(16.71 \%)$, although the percentages of slightly negative (28.83) and slightly positive sentiments (26.67) are similar.

Table 3. This is a figure. Schemes follow the same formatting.

\begin{tabular}{ccccc}
\hline & Very Negative & $\begin{array}{c}\text { Slightly } \\
\text { Negative }\end{array}$ & $\begin{array}{c}\text { Slightly } \\
\text { Positive }\end{array}$ & Very Positive \\
\hline Man & $27.79 \%$ & $28.83 \%$ & $26.67 \%$ & $16.71 \%$ \\
Woman & $30.02 \%$ & $29.01 \%$ & $26.78 \%$ & $14.19 \%$ \\
\hline
\end{tabular}

Source: Produced by the author.

It is, however, of interest to analyse these data according to the speakers' profiles. Despite the fact that the sample is limited, if we take gender into account, we find a slight prevalence of negative sentiments in interactions with the content created by women that is 2.41 percentage points higher than for men (59.03\% compared with $56.62 \%)$. The greatest difference is found at the extremes: women received more "very negative" and fewer "very positive" comments.

\section{Conclusions and Discussion}

The analysis of the dissemination content published on the TED Talks platform concerning topics connected with the COVID-19 pandemic first of all serves to confirm the speed with which the scientific and educational community adapted to the situation imposed by the health crisis and responded to the demand for information among the general public, through audiovisual publications using relatable language. Citizens' concern about misinformation during the first months of the pandemic has provided the media the opportunity to show their credibility as information sources, a "trust halo" that has been especially effective on the Web (Newman et al. 2020).

The research likewise corroborated a number of the issues indicated by prior research as to the gender gap in the scientific community. The difference in male and female authorship was thus 15.62 percentage points, which although significant, is less than that recorded by other studies (Sugimoto et al. 2013). This could be connected with the fact that some studies indicate that, while being a useful tool to inform society about science, 
such dissemination exercises are not reflected in a positive manner in the academic impact of scientists (Sugimoto et al. 2013), being in essence more based in the community, a field where women tend to have a greater presence.

Meanwhile, the qualitative analysis of the data indicates a much more extensive gap, since during the first five months of the pandemic, when the topic was of greatest social interest and had a much greater information impact, the gap spread to 27.28 points. As interest declined, along with the volume of publications, the number of women increased. This could be affected by the fact that caring duties during lockdown mainly fell to women (Myers et al. 2020), because of the existence of greater difficulties in reconciling family and work life (Krukowski et al. 2021; Deryugina et al. 2021), or that men might opt for higher-profile topics with more publishable characteristics (Lerchenmueller et al. 2019).

Although legislative changes and the application of equality policies, as well as the expansion of opportunities and socioeconomic changes in gender relations have contributed to increasing the number of women in the scientific field, there are still other factors that explain the existing gap, such as the lower presence of women in training programs in these areas, as well as stereotypes and the social construction of science (Vázquez-Cupeiro 2015).

In general, the descriptive analysis indicated a greater presence of male rather than female experts, although the difference is less than in other spheres, such as the traditional media. This could suggest that these more informal offerings provide women with greater space for participation, or generate less of a sense of reluctance. The individualized participation that is typical of dissemination efforts, as opposed to the dominating (and masculinized) team research in science (Kwiek and Roszka 2021), could be a factor that explains this difference.

In the case of TED talks on COVID-19, it is nonetheless true that in the case of men, the percentage of interviews is significantly higher, which could indicate that in content where the platform has a higher degree of intermediation, men have a more significant presence. In this regard, the relations of gender would be hierarchical and inequality would be a central feature of science, showing a wide range of gender disparities in collaboration team compositions, divisions of labor and power dynamics, integration into departmental units, and international co-authorship (Fox 2020).

Differences may similarly be noted in the topics addressed. Although the central strand of the content analysed is the health crisis caused by COVID-19, healthcare, social and economic perspectives prevail (Eizmendi and Peña-Fernández 2021). There are significant differences in terms of the authorship of healthcare topics, bearing in mind that this is a sphere in which women make up the majority (Vázquez-Vega 2010). The issues where women stand out are art and politics, in the latter case in particular with reference to the management of the health crisis. For their part, men reveal a significantly greater percentage in topics connected with technology and climate change, issues that have a more innovative profile.

The qualitative analysis of the publications furthermore reveals a greater inclination on the part of women towards community-based and social interaction issues, and a discourse focused more on the characteristics of the virus, its origins, and the vaccine in the case of men, issues that are likewise prominent in the analysis of the resulting comments. While the presence of women as authors of audiovisual content is, then, greater compared with other media, their contributions reveal significant differences compared with those made by men.

In turn, content created by men obtained a significantly greater number of views and interactions, whether positive or negative. However, women generally received a somewhat greater percentage of negative comments ( $2.41 \%$ higher). This confirms the trends revealed previously by other studies, which in studying the presence of female academics on the YouTube platform, emphasise that they are more likely to receive more negative comments (Amarasekara and Grant 2019; Tsou et al. 2014).

In conclusion, although the analysis of the content published on the TED Talks site about COVID-19 suggests that female experts-both academics and non-academics-have 
a higher percentage of involvement than in other more traditional formats, the analysis of content and engagement suggests that their contribution reveals distinctive characteristics when compared with men, and they generate a smaller and more critical response.

This fact acquires more relevance if we take into account the lower visibility and the stereotyped image that is offered of female scientists, a projection that does not respond to the advances that they have experienced in the scientific and academic field. Therefore, these platforms also do not represent an opportunity to normalize and equalize the contributions of women to science.

These data are of value in understanding the communication and reception trends developing on one of the most successful online dissemination platforms, taking as the backdrop what may be one of the most disruptive and significant events of the 21st century in scientific, social and communication terms.

Nonetheless, in order better to understand the reality studied, likewise from a comparative perspective, it would be of interest to analyse the communication strategies used on these platforms beyond this specific context, along with other online dissemination initiatives.

Author Contributions: Conceptualization, M.E.; methodology, M.E.; software, M.E.; validation, M.E. and S.P.-F.; formal analysis, M.E. and S.P.-F.; investigation, M.E.; resources, M.E.; data curation, M.E.; writing—original draft preparation, M.E.; writing—review and editing, S.P.-F.; visualization, S.P.-F.; supervision, M.E. and S.P.-F.; project administration, S.P.-F.; funding acquisition, S.P.-F. All authors have read and agreed to the published version of the manuscript.

Funding: This research was funded by the Spanish Ministry of Science, Innovation and Universities, grant number RTI2018-095775-B-C41 and Basque Government, grant number IT-1112.

Institutional Review Board Statement: Not applicable.

Informed Consent Statement: Not applicable.

Data Availability Statement: A summary of the data is available at https:/ / doi.org/10.5281/zenodo. 5628337 (last accessed on 2 December 2021). Other data presented in this study are available on request from the corresponding author.

Conflicts of Interest: The authors declare no conflict of interest.

\section{References}

Aladro, Eva, Graciela Padilla, Paula Requeijo, Dimitrina Semova, Julia García-Agustín, María Teresa García-Nieto, and Mónica Viñarás. 2014. La presencia y representación de la mujer científica en la prensa española. Revista Latina de Comunicación Social 69: 176-94. [CrossRef]

Amarasekara, Inoka, and Will J. Grant. 2019. Exploring the YouTube science communication gender gap: A sentiment analysis. Public Understanding of Science 28: 68-84. [CrossRef]

Andersen, Jeans P., Mathias W. Nielsen, Nicole L. Simone, Resa E. Lewiss, and Reshma Jagsi. 2020. Meta-Research: COVID-19 medical papers have fewer women first authors than expected. eLife 9: e58807. [CrossRef] [PubMed]

Andreu, Jaime. 2001. Las Técnicas de Análisis de Contenido: Una Revisión Actualizada. Available online: http://mastor.cl/blog/wpcontent/uploads/2018/02/Andreu.-analisis-de-contenido.-34-pags-pdf.pdf (accessed on 30 November 2021).

Anzivino, Monia. 2021. Is public engagement gendered? An analytical proposal using some evidence from Italy. Public Understanding of Science 30: 827-40. [CrossRef]

Cambronero-Saiz, Belén, Jesús Segarra-Saavedra, and Carmen Cristófol-Rodríguez. 2021. Análisis desde la perspectiva de género del engagement de los principales youtubers de divulgación científica= Analysis of the engagement of the main popular science youtubers from a gender perspective. Cuestiones de Género: De la Igualdad y la Diferencia 16: 511-25. [CrossRef]

Carli, Linda, Laila Alawa, YoonAh Lee, Zhao Bei, and Elaine Kim. 2016. Stereotypes about gender and science: Women $\neq$ scientists. Psychology of Women Quarterly 40: 244-60. [CrossRef]

Casero-Ripollés, Andreu. 2020. Impact of Covid-19 on the media system. Communicative and democratic consequences of news consumption during the outbreak. El Profesional de la Información 29: e290223. [CrossRef]

Ceron, Wilson, Mathias-Felipe de-Lima-Santos, and Marcos G. Quiles. 2021. Fake news agenda in the era of COVID-19: Identifying trends through fact-checking content. Online Social Networks and Media 21: 100116. [CrossRef]

Chinetti, Simone. 2021. Academic Productivity and Pandemic. Evidence from Female Economists during the COVID-19 Crisis. Available online: http:/ / www.siepweb.it/siep/images/candidati_chiuri_2021/Chinetti.pdf (accessed on 30 November 2021). 
Côté, Isabelle, and Emily Darling. 2018. Scientists on Twitter: Preaching to the choir or singing from the rooftops? Facets 3: 682-94. [CrossRef]

Deryugina, Tatyana, Olga Shurchkov, and Jenna Stearns. 2021. Covid-19 disruptions disproportionately affect female academics. AEA Papers and Proceedings 111: 164-68. [CrossRef]

Diviu-Miñarro, Clàudia, and Sergio Cortiñas-Rovira. 2020. Cómo comunicar una pandemia a la sociedad: La visión de los profesionales. Estudio de caso de la Covid-19 en el sur de Europa. El Profesional de la Informacion 29: 1-14. [CrossRef]

Duch, Jordi, Xiao Han T. Zeng, Marta Sales-Pardo, Filippo Radicchi, Shayna Otis, Teresa K. Woodruff, and Luís A. Nunes Amaral. 2012. The possible role of resource requirements and academic career-choice risk on gender differences in publication rate and impact. PLoS ONE 7: e51332. [CrossRef] [PubMed]

Eizmendi, Maider, and Simón Peña-Fernández. 2021. ¿Desaparecidas o escondidas? Análisis de la presencia de las ciencias sociales y las humanidades en las versiones online de The Guardian, El País y Público. European Public E Social Innovation Review 6: 56-69. Available online: https://pub.sinnergiak.org/esir/article/view/147 (accessed on 2 December 2021).

Fox, Mary Frank. 2020. Gender, science, and academic rank: Key issues and approaches. Quantitative Science Studies 1: 1001-6. [CrossRef]

Husu, Liisa, and Liisa Tainio. 2016. Representations of Women Researchers in Finnish Print Media: Top Researchers, Multi-Talents and Experts. Investigationes Feministas 7: 203-24. [CrossRef]

Kalia, Vivek, Amy K. Patel, Andrew K. Moriarity, and Cheri L. Canon. 2017. Personal branding: A primer for radiology trainees and radiologists. Journal of the American College of Radiology 14: 971-75. [CrossRef]

Kedrowicz, April A., and Julie L. Taylor. 2016. Shifting Rhetorical Norms and Electronic Eloquence: TED Talks as Formal Presentations. Journal of Business and Technical Communication 30: 352-77. [CrossRef]

King, Molly M., and Megan E. Frederickson. 2021. The Pandemic Penalty: The gendered effects of COVID-19 on scientific productivity. Socius 7. [CrossRef]

Krukowski, Rebecca A., Reshma Jagsi, and Michelle I. Cardel. 2021. Academic productivity differences by gender and child age in science, technology, engineering, mathematics, and medicine faculty during the COVID-19 pandemic. Journal of Women's Health 30: 341-47. [CrossRef] [PubMed]

Kwiek, Marek, and Wojciech Roszka. 2021. Are Female Scientists Less Inclined to Publish Alone? The Gender Solo Research Gap. arXiv arXiv:2101.03220.

Larivière, Vincent, Chaoqun Ni, Yves Gingras, Blaise Cronin, and Cassidy R. Sugimoto. 2013. Bibliometrics: Global gender disparities in science. Nature News 504: 211-13. [CrossRef] [PubMed]

Lerchenmueller, Marc J., Olav Sorenson, and Anupam B. Jena. 2019. Gender differences in how scientists present the importance of their research: Observational study. BMJ 367: 16573. [CrossRef] [PubMed]

Mitchell, Madeline, and Merryn McKinnon. 2019. 'Human' or 'objective' faces of science? Gender stereotypes and the representation of scientists in the media. Public Understanding of Science 28: 177-90. [CrossRef]

Mitchelstein, Eugenia, Victoria Andelsman, and Pablo Boczkowski. 2019. Joanne Public vs. Joe Public: News sourcing and gender imbalance on Argentine digital media. Digital Journalism 7: 1311-27. [CrossRef]

Mueller, Claudia M., Dyani K. Gaudilliere, Roseanne Menorca, and Sabine Girod. 2016. Gender disparities in scholarly productivity of US academic surgeons. Journal of Surgical Research 203: 28-33. [CrossRef] [PubMed]

Myers, Kyle R., Wei Yang Tham, Yian Yin, Nina Cohodes, Jerry G. Thursby, Marie C. Thursby, Peter Schiffer, Joseph T. Walsh, Karim R. Lakhani, and Dashun Wang. 2020. Unequal effects of the COVID-19 pandemic on scientists. Nature Human Behaviour 4: 880-83. [CrossRef] [PubMed]

Newman, Nic, Richard Fletcher, Anne Schulz, Simge Andi, and Rasmus Kleis Nielsen. 2020. Reuters Institute Digital News Report. Oxford: University of Oxford, Available online: https://reutersinstitute.politics.ox.ac.uk/sites/default/files/2020-06/DNR_2020 _FINAL.pdf (accessed on 30 November 2021).

Palomar Verea, Cristina. 2009. Maternidad y mundo académico. Alteridades 19: 55-73. Available online: http:/ /www.scielo.org.mx/ scielo.php?script=sci_arttext\&pid=S0188-70172009000200005\&lng=es\&tlng=es (accessed on 30 November 2021).

Pereira, Maria do Mar. 2021. Researching gender inequalities in academic labor during the COVID-19 pandemic: Avoiding common problems and asking different questions. Gender, Work \& Organization 28: 498-509. [CrossRef]

Pérez-Dasilva, Jesús A., Koldobika Meso-Ayerdi, and Terese Mendiguren-Galdospin. 2020. Fake news y coronavirus: Detección de los principales actores y tendencias a través del análisis de las conversaciones en Twitter. Profesional de la Información 29: e290308. [CrossRef]

Peters, Hans P., Sharon Dunwoody, Joachim Allgaier, Yin-Yueh Lo, and Dominique Brossard. 2014. Public communication of science 2.0: Is the communication of science via the "new media" online a genuine transformation or old wine in new bottles? EMBO Reports 15: 749-53. [CrossRef]

Schwemmer, Caster, and Sebastian Jungkunz. 2019. Whose ideas are worth spreading? The representation of women and ethnic groups in TED talks. Political Research Exchange 1: 1-23. [CrossRef]

Sierra-Rodríguez, J. 2020. Periodismo, comunicación institucional y transparencia: Aprendizajes de la crisis sanitaria del COVID-19. Revista de Comunicación y Salud: RCyS 10: 569-91. [CrossRef]

Sugimoto, Cassidy, Mike Thelwall, Vincent Larivière, Andrew Tsou, Phillippe Mongeon, and Benoit Macaluso. 2013. Scientists Popularizing Science: Characteristics and Impact of TED Talk Presenters. PLoS ONE 8: e62403. [CrossRef] 
Tsou, Andrew, Mike Thelwall, Phillippe Mongeon, and Sugimoto Cassidy. 2014. A Community of Curious Souls: An Analysis of Commenting Behavior on TED Talks Videos. PLoS ONE 9: e93609. [CrossRef]

Vázquez-Cupeiro, Susana. 2015. Science, stereotypes and gender: A review of the explanatory frameworks. Convergencia 22: 177-202. Vázquez-Vega, Pablo, ed. 2010. La Feminización de las Profesiones Sanitarias. Madrid: Fundación BBVA.

Veletsianos, George, Royce Kimmons, Ross Larsen, Tonia A, Dousay T., and Patrick Lowenthal. 2018. Public comment sentiment on educational videos: Understanding the effects of presenter gender, video format, threading, and moderation on YouTube TED talk comments. PLoS ONE 13: e0197331. [CrossRef] [PubMed]

Welbourne, Dustin J., and Will J. Grant. 2016. Science communication on YouTube: Factors that affect channel and video popularity. Public Understanding of Science 25: 706-18. [CrossRef]

Wimmer, Roger, and Joseph Dominick. 1996. La Investigación Científica de los Medios de Comunicación. Barcelona: Bosch Comunicación.

Wright, Katharine A., Toni Haastrup, and Roberta Guerrina. 2021. Equalities in freefall? Ontological insecurity and the long-term impact of COVID-19 in the academy. Gender, Work \& Organization 28: 163-67. [CrossRef] 